\title{
Meningkatkan Prestasi Belajar Agama Hindu Melalui Penerapan Model Pembelajaran Creative Problem Solving dengan Metode Pemberian Tugas Individu dalam Kerja Kelompok
}

\author{
I Wayan Sewela*
}

SD Negeri 1 Bakbakan

\author{
A R T I C L E I N F O \\ Article history: \\ Received 18 August 2019 \\ Received in revised form \\ 19 September 2019 \\ Accepted 25 October 2019 \\ Available online 30 \\ November 2019 \\ Kata Kunci: \\ Model Pembelajaran \\ Creative Problem Solving, \\ Metode Pemberian Tugas \\ Individu Dalam Kerja \\ Kelompok, Prestasi Belajar \\ Keywords: \\ Creative Problem Solving \\ Learning Model, Individual \\ Assignment Method in \\ Group Work, Learning \\ Achievement
}

\begin{abstract}
A B S T R A K
Penelitian ini dilaksanakan di SD Negeri 1 Bakbakan di kelas VI yang kemampuan siswanya untuk mata pelajaran Agama Hindu masih sangat rendah. Tujuan penulisan penelitian tindakan kelas ini adalah untuk meningkatkan prestasi belajar Agama Hindu siswa kelas VI SD Negeri 1 Bakbakan pada semester II tahun pelajaran 2017/2018 melalui penerapan model pembelajaran Creative Problem Solving dengan metode pemberian tugas individu dalam kerja kelompok. Metode pengumpulan datanya adalah observasi dan tes prestasi belajar. Metode analisis datanya adalah deskriptif. Dengan hasil yang diperoleh dari penelitian ini adalah model pembelajaran yang diterapkan dapat meningkatkan prestasi belajar siswa. Ini terbukti dari hasil yang diperoleh pada awalnya hanya mencapai rata-rata 65,35 dan ketuntasan belajar $28,57 \%$, pada siklus I meningkat menjadi 73,57 dengan ketuntasan belajar $64,28 \%$ dan pada Siklus II meningkat menjadi 84,28 dengan ketuntasan belajar mencapai 96,42\%. Kesimpulan yang diperoleh dari penelitian ini adalah penggunaan model pembelajaran Creative Problem Solving dengan metode pemberian tugas individu dalam kerja kelompok dapat meningkatkan prestasi belajar Agama Hindu siswa kelas VI SD Negeri 1 Bakbakan pada semester II tahun pelajaran 2017/2018.
\end{abstract}

\section{A B S T R A C T}

This research was conducted at SD Negeri 1 Bakbakan in class VI where the ability of students for Hindu subjects was still very low. The purpose of writing this class action research is to improve the learning achievement of Hindu Religion grade VI students at SD Negeri 1 Bakbakan in the second semester of the 2017/2018 academic year through the application of the Creative Problem Solving learning model with the method of giving individual assignments in group work. Data collection methods are observation and achievement test. The data analysis method is descriptive. With the results obtained from this study are applied learning models can improve student achievement. This is evident from the results obtained initially only reached an average of 65.35 and mastery learning $28.57 \%$, in the first cycle increased to 73.57 with mastery learning $64.28 \%$ and in Cycle II increased to 84.28 with completeness learning reached $96.42 \%$. The conclusion obtained from this study is the use of Creative Problem Solving learning models with individual assignment methods in group work can improve learning achievement of Hindu Religion grade VI students of SD Negeri 1 Bakbakan in semester II of the academic year 2017/2018.

\footnotetext{
${ }^{1}$ Corresponding author.

E-mail addresses: iwayanswela01@Gmail.com (I Wayan Sewela)
} 


\section{Pendahuluan}

Pendidikan merupakan kegiatan yang universal dalam kehidupan manusia, dengan pendidikan manusia berusaha mengembangkan potensi yang dimilikinya, mengubah tingkah laku ke arah yang lebih baik. Tujuan pendidikan nasional adalah mengupayakan perluasan dan pemerataan kesempatan memperoleh pendidikan yang bermutu tinggi bagi seluruh rakyat Indonesia sendiri secara optimal disertai dengan hak dukungan dan lindungan sesuai dengan potensinya. Sebagai perwujudan pencapaian tujuan tersebut maka belajar merupakan suatu proses aktif memerlukan dorongan dan bimbingan ke arah tercapainya tujuan yang dikehendaki [1]. Salah satu permasalahan mutu pendidikan di Indonesia adalah rendahnya mutu proses pembelajaran seperti metode mengajar guru yang tidak tepat, kurikulum, manajemen sekolah yang tidak efektif dan kurangnya motivasi siswa dalam belajar. Hasil survei PISA (Programme for International Student Assesment) terakhir pada tahun 2012 menunjukkan bahwa bidang sains Indonesia menduduki peringkat 64 dari 65 negara. Ditemukan bahwa negara dengan siswa yang memiliki keyakinan akan kemampuannya akan meningkatkan prestasi mereka. Selain itu semakin mereka menikmati belajar, semakin tinggi prestasi belajar mereka [2]. Hal ini menujukkan bahwa motivasi mempunyai peranan yang cukup besar di dalam upaya belajar. Untuk mendukung siswa termotivasi dalam belajar maka harus didukung dengan suasana pembelajaran yang kondusif. Kondisi belajar mengajar yang efektif adalah adanya minat perhatian siswa dalam belajar [3]. Dalam interaksi belajar mengajar terdapat berbagai macam model pembelajaran yang bertujuan agar proses belajar mengajar dapat berjalan baik. Hal ini juga bertujuan untuk menciptakan proses belajar mengajar aktif srta memungkinkan timbulnya sikap ketertarikan siswa terhadap proses pembelajaran sehingga apabila siswa memiliki ketertarikan dengan model suatu pembelajaran, maka akan menjamin siswa dapat menyerap materi yang diajarkan secara maksimal. Salah satu model pembelajaran yang dapat menciptakan kegiatan proses belajar mengajar menyenangkan dan menarik yaitu model pembelajaran kooperatif tipe artikulasi. Model pembelajaran kooperatif tipe artikulasi merupakan model pembelajaran yang prosesnya seperti pesan berantai, artinya seorang siswa wajib meneruskan menjelaskan pada siswa lain sebagai pasangannya materi yang sudah dijelaskan oleh guru, kemudian siswa yang menyimak berganti peran menjelaskan kepada pasangannya (Wepe, 2016).

Pendidikan merupakan kebutuhan mutlak bagi kehidupan manusia yang harus dipenuhi. Tanpa pendidikan mustahil manusia dapat berkembang secara baik. Pendidikan dapat diartikan sebagai sebuah proses dengan metode-metode tertentu sehingga orang memperoleh pengetahuan, pemahaman, dan cara bertingkah laku yang sesuai dengan kebutuhan. Penyelenggaraan pendidikan di Indonesia menurut UU Nomor 20 Tahun 2003 pasal 1 ayat (2) disebutkan bahwa suatu Pendidikan Nasional adalah pendidikan yang berdasarkan Pancasila dan Undang-Undang Dasar 1945 yang berakar pada nilai-nilai agama, kebudayaan nasional Indonesia dan tanggap terhadap tuntutan perubahan zaman.

Pendidikan adalah aspek penting bagi pengembangan sumber daya manusia. Pendidikan juga diyakini mampu menanamkan pengalaman bagi semua orang untuk mempelajari pengetahuan dan keterampilan sehingga dapat diperoleh manusia yang produktif. Salah satu hal yang paling mendasar dalam dunia pendidikan adalah bagaimana usaha untuk menginovasi proses pembelajaran sehingga memperoleh hasil yang maksimal

Guru sebagai ujung tombak pendidikan dan keberhasilan pelaksanaan UU Sistem Pendidikan, diharapkan memiliki pengetahuan dan keterampilan yang berhubungan dengan tugas dan tanggung jawabnya selaku guru yang profesional. Guru yang profesional harus memiliki seperangkat kompetensi (pengetahuan, keterampilan dan perilaku) untuk mampu menjalankan tugas yang diembannya. Berdasarkan UU no. 14 Tahun 2005 tentang Guru dan Dosen pada Bab IV Pasal 10 ayat (1) menyatakan bahwa Kompetensi guru sebagaimana dimaksud dalam Pasal 8 meliputi kompetensi pedagogik, kompetensi kepribadian, kompetensi sosial, dan kompetensi profesional yang diperoleh melalui pendidikan profesi.

Sementara menurut Saud (2012: 50) Proyek Pembinaan Pendidikan Guru (P3G) telah merangkum kompetensi guru di Indonesia yang meliputi: (1) menguasai bahan; mengelola program belajar-mengajar; menggunakan media/sumber belajar; menguasai landasan kependidikan; mengelola interaksi belajarmengajar; menilai prestasi belajar ; mengenal fungsi dan layanan bimbingan penyuluhan; mengenal dan menyelenggarakan administrasi sekolah; dan memahami dan menafsirkan hasil penelitian guna keperluan pengajaran.

Beranjak dari apa yang disampaikan oleh Cooper menyangkut masalah profesionalisme guru, Wina Sanjaya juga menyatakan bahwa untuk meyakinkan bahwa guru sebagai pekerjaan professional, marilah kita tinjau syarat-syarat atau ciri pokok dari pekerjaan profesional. (a) Pekerjaan profesional ditunjang oleh suatu ilmu tertentu secara mendalam yang hanya mungkin didapatkan dari lembaga-lembaga pendidikan yang sesuai, sehingga kinerjanya didasarkan kepada keilmuan yang dimilikinya yang dapat 
dipertanggungjawabkan secara ilmiah. (b) Suatu profesi menekankan kepada suatu keahlian dalam bidang tertentu yang spesifik sesuai dengan jenis profesinya, sehingga antaraprofesi yang satu dengan yang lainnya dapat dipisahkan secara tegas. (c) Tingkat kemampuan dan keahlian suatu profesi didasarkan kepadalatar belakang pendidikan yang dialaminya yang diakui oleh masyarakat, sehingga semakin tinggi latar belakang pendidikan akademis sesuai dengan profesinya, semakin tinggi pula tingkat keahliannyadengan demikian semakin tinggi pula tingkat penghargaan yang diterimanya. (d) Suatu profesi selain dibutuhkan oleh masyarakat juga memiliki dampak terhadap sosial kemasyarakatan, sehingga masyarakat memiliki kepekaan yang sangat tinggi terhadap setiap efek yang ditimbulkan menyadari pekerjaan profesinya itu (Sanjaya, 2010: 275).

Sementara itu, Ali Idrus menyatakan untuk menghadapi tantangan zaman dengan kemajuan teknologi informasi dan ilmu pengetahuan yang serba cepat dibutuhkan guru profesional yang intelektual dan bermoral. Hal itu sesuai dengan pendapat Giroux (1988) yang disampaikannya bahwa sosok guru yang mampu memunculkan inovasi dalam pendidikan adalah guru yang menurutnya mau terus berkembang dan belajar seumur hidup, tidak pernah puas dengan apa yang dimengerti, mau membawa perubahan, berpikir kritis, rasional bebas mengembangkan pikiran, reflektif, berani membela kebenaran dan keadilan. Dan tidak dibutuhkan guru yang hanya mempertahankan status quo-nya dan menjalankan tugasnya seperti tukang (Idrus, 2009: 157).

Berbagai laporan mengungkapkan bahwa prestasi belajar (academic achievement) peserta didik Indonesia kurang optimal. Laporan-laporan tersebut antara lain oleh The International Association for the Evaluation of Educational Achievement (IEA) Tahun 2011. IEA merupakan salah satu lembaga Internasional independen, melakukan penelitian dan studi dalam skala besar mengukur perbandingan prestasi dan aspek-aspek lain pendidikan di 64 negara di dunia sebagai peserta. Dari hasil pengukuran kemampuan bidang IPA dan matematika Internasional, pelajar SMP Indonesia berada pada urutan 38 dari 39 negara yang disurvei (IEA, 2011), sedangkan hasil pengukuran Trends in International Mathematics and Science Study (TIMSS) Tahun 2011, kemampuan matematika pelajar SMP Indonesia juga berada pada urutan 34 dari 38 negara, sedangkan kemampuan pelajar Indonesia pada bidang IPA berada di urutan ke 32 dari 38 negara yang disurvei (TIMSS, 2011). Kualitas pendidikan Indonesia seperti yang dilaporkan oleh The International Association for the Evaluation of Educational Achievement (IEA) dan Trends in International Mathematics and Science Study (TIMSS), perlu dicermati dan ditindaklanjuti. Berdasarkan pralapangan diketahui bahwa SMA Negeri 1 Lawang Kabupaten Malang: skor rata-rata nilai Ujian Nasional (UN) lima mata pelajaran perolehan nilai dengan rentang skor 8.6 sampai dengan 10 hanya diperoleh oleh 26 dari 412 peserta didik yang ikut dan dinyatkan lulus UN 2012. Hal ini berarti bahwa hanya 6.28\% lulus dengan prestasi belajar yang baik, sementara 274 peserta didik (66.52\%) berada pada posisi sedang dan 112 peserta didik (27.20\%) berada pada posisi rendah. Lebih lanjut, penelusuran literatur, cukup banyak penelitian yang mencoba mengungkapkan kasus menyontek. Penelitian Rittman (1996); Bogle (2000); dan Turrens, dkk., (2002) mencoba mengungkap perilaku menyontek dengan angket sebagai alat instrumenasinya. Penelitian Thorpe, dkk., (1999) perilaku menyontek terjadi karena nilai pelajar rendah karena kemampuannya memang rendah, ia memiliki hasrat untuk mendapatkan nilai belajar yang lebih tinggi (Yuzarion, 2017).

Menyadari permasalahan yang sedang dihadapi, untuk mendukung semua yang telah dijelaskan di atas. Guru selaku peneliti yang bertugas di SD Negeri 1 Bakbakan mencoba melakukan koreksi dan refleksi atas prestasi belajar awal siswa kelas VI semester II tahun pelajaran 2017/2018 yang ditemukan pada saat observasi. Rata-rata nilai mata pelajaran Agama Hindu siswa yang diperoleh hanya mencapai 65,35 dengan prosentase ketuntasan belajar sebesar $28,57 \%$. Nilai tersebut ternyata masih jauh dari Kriteria Ketuntasan Minimal (KKM) yang ditetapkan sekolah yaitu 75.

Pengamatan dan perenungan kembali jalannya proses pembelajaran yang telah dilakukan membuahkan kesimpulan beberapa faktor yang penyebabnya adalah(a) kurang seriusnya guru dalam melakukan persiapan untuk memulai proses pembelajaran; (b) kurangnya daya dukung berupa media/sumber belajar yang dimanfaatkan guru saat pelaksanaan pembelajaran, dan (c) kurangnya daya kreativitas siswa akibat waktu belajar banyak dikuasai guru sehingga ketika usai proses pembelajaran pengetahuan dan pemahaman yang harusnya dikuasai siswa belum tecapai.

Mempertimbangkan kondisi tersebut, guru melakukan konsultasi dengan beberapa teman sejawat dan ditemukan solusi yang menurut pertimbangan guru akan mampu menuntaskan permasalahan yang sedang dihadapi. Solusi tersebut adalah mengupayakan model pembelajaran berbasis masalah untuk melatih siswa agar dapat berpikir kreatif dan kritis menghadapi masalah. Dukungan yang disiapkan guru untuk mewujudkan hal itu dengan mengupayakan dan memanfaatkan media pembelajaran yang mampu menarik minat dan konsentrasi mereka untuk belajar. Hal itu dilakukan mempertimbangkan apa yang disampaikan Darmawan (2009: 66) yang mengkaji tentang media, model pembelajaran, dan perilaku belajar peserta didik, dengan pernyataan bahwa peranan teknologi informasi dan komunikasi dalam 
mengemas informasi pembelajaran akan memperkuat stimulus dalam proses pembelajaran. Dengan stimulus ini pembelajar akan mampu mengoptimalkan perilaku belajarnya.

Itu berarti, kuatnya stimulus yang diberikan guru berpengaruh sangat besar untuk memunculkan minat, motivasi, konsentrasi dan semangat belajar siswa. Dewasa ini, stimulus terkuat yang mampu mempengaruhi semua orang adalah multimedia komputer/laptop. Manfaat penggunaan multimedia dalam proses pembelajaran juga diungkapkan Schramm (1984) mengemukakan bahwa komputer memiliki kemampuan yang luar biasa dibandingkan media lainnya, dan aplikasi software pembelajaran merupakan salah satu sumber belajar yang dirancang (learning resources by design) dimana di dalamnya telah disiapkan untuk tujuan pembelajaran tertentu. Arsyad (2006) menyebutnya sebagai media mutahir berbasis komputer yang diyakini mampu menciptakan pembelajaran yang lebih "hidup" dan dan melibatkan interaktifitas siswa (Buchori, 2012).

Dasar kajian inilah yang kemudian dijadikan landasan guru untuk melakukan pembuktian sendiri dalam proses pembelajaran yang dilakukan, sejauh mana model pembelajaran yang dilaksanakan secara kreatif dengan media pembelajaran yang bertumpu pada kemajuan teknologi informasi dapat meningkatkan prestasi belajar siswa

Adapun langkah yang diambil untuk memperbaiki prestasi belajar siswa yaitu dengan tindakan perbaikan yang selanjutnya disusun dalam bentuk penelitian tindakan kelas. Dengan cara ini diharapkan peserta didik akan tertarik untuk berinteraksi dalam pembelajaran sehingga akan meningkatkan kemampuan dan keterampilannya.

\section{Metode}

Penelitian yang dilakukan termasuk penelitian tindakan. Oleh karenanya, rancangan yang khusus untuk sebuah penelitian tindakan sangat diperlukan. Peningkatan diri untuk hal yang lebih baik ini dilakukan terus menerus sampai tujuan tercapai (Suharsimi Arikunto, Suhardjono, Supardi, 2006: 6-7).

Dalam melaksanakan penelitian, rancangan merupakan hal yang sangat penting untuk disampaikan. Tanpa rancangan, bisa saja alur penelitian akan ngawur dalam pelaksanaannya. Secara operasional prosedur dasar pengembangan tindakan yang akan dilakukan dapat dijabarkan sebagai berikut:

Mc. Kernan

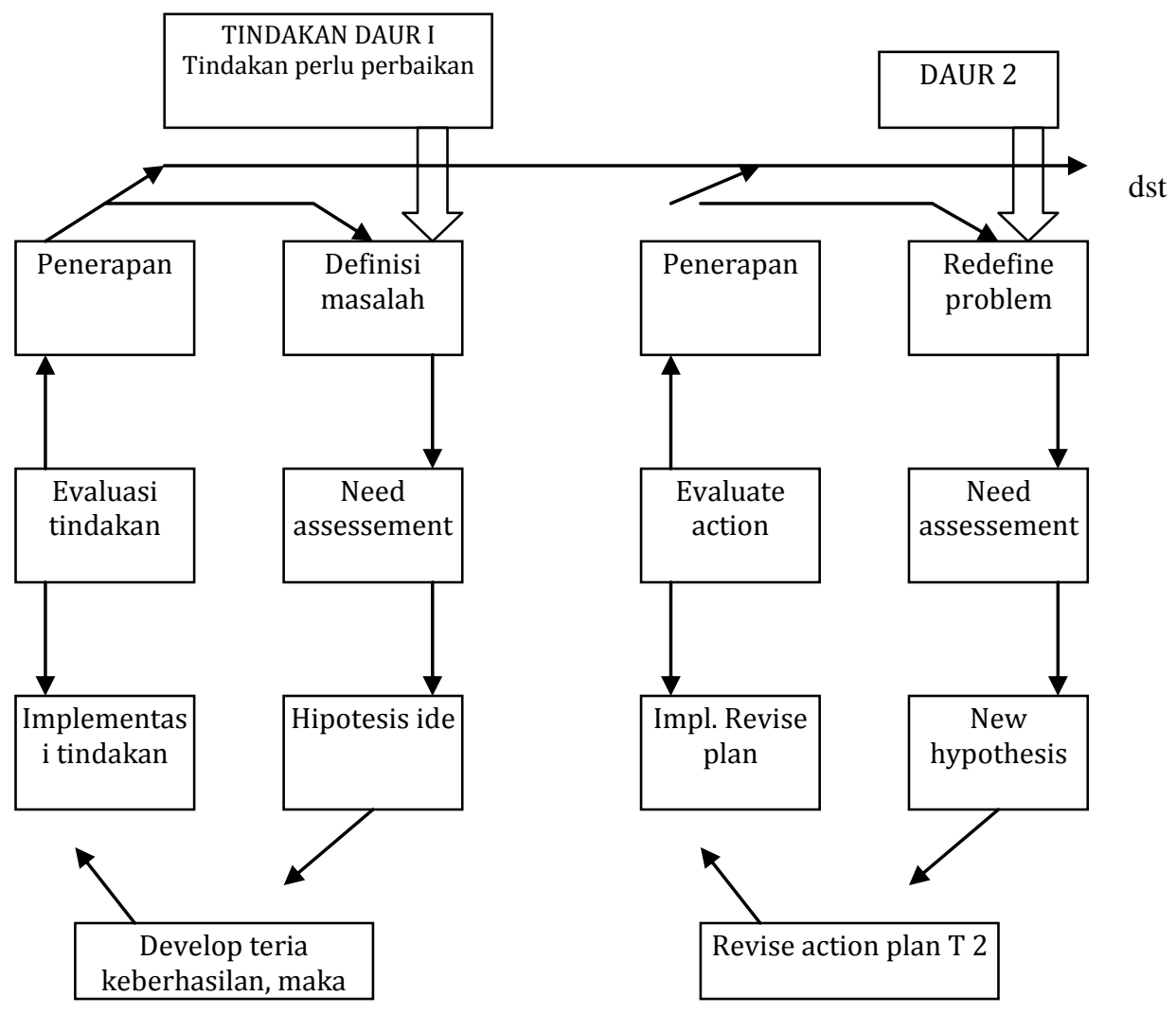

Gambar 1. Penelitian Tindakan Model Mc. Kernan, 1991 (dalam Sukidin, Basrowi, Suranto, 2002: 54) 
Prosedur:

Tindakan daur I dilakukan definisi masalah dilanjutkan dengan pelaksanaan di lapangan, dirumuskan hipotesisnya, dikembangkan hipotesis tersebut, diimplementasikan, dievauasi dari hasil yang didapat dan evaluasi diterapkan. Langkah-langkah pada daur II atau siklus II sama dengan yang di siklus I yaitu dimulai dengan adanya suatu permasalahan yang baru, didefinisikan masalahnya, dibuat hipotesisnya direvisi, selanjutnya dialkukan implementasi di lapangan, dievaluasi, kemudian hasil yang didapat merupakan penerapanbaru apabila masih adalah masalah.

Untuk mengumpulkan data penelitian ini digunakan tes hasil belajar. Tes ini berupa tes tulis yang berjumlah antara 10 soal.

Metode yang digunakan untuk menganalisis data hasil penelitian ini adalah metode deskriptif. Untuk data kuantitatif dianalisis dengan mencari mean, median, modus, membuat interval kelas dan melakukan penyajian dalam bentuk tabel dan grafik.

1. Rata-rata (mean) dihitung dengan:

\section{Jumlah willai}

Jumlah siswa

2. Median (titik tengahnya) dicari dengan mengurut data/nilai siswa dari yang terkecil sampai terbesar. Setelah diurut apabila jumlah data ganjil maka mediannya adalah data yang di tengah. Kalau jumlahnya genap maka dua data yang di tengah dijumlahkan dibagi 2 (dua).

3. Modus (angka yang paling banyak/paling sering muncul).

Dalam penelitian ini diusulkan tingkat keberhasilan pada siklus I dan siklus II mencapai hasil/nilai rata-rata 75,00 dengan ketuntasan belajar mencapai 85\%.

\section{Hasil dan Pembahasan}

1) Berdasarkan Hasil yang diperoleh dari kegiatan awal:

Hasil yang menunjukan perolehan nilai rata rata kelas prestasi belajar Agama Hindu masih sangat rendah, yaitu dengan perolehan skor nilai secara klasikal yaitu 1830 dan rata rata hanya mencapai 65,35, dimana siswa yang mencapai persentase ketuntasan belajar 28,57\%, dan yang tidak mencapai ketuntasan adalah 71,42\%, dengan tuntutan KKM untuk mata pelajaran Agama Hindu di kelas VI SD Negeri 1 Bakbakan adalah dengan nilai 75.

2) Hasil pada siklus I:

Pada siklus I sudah diupayakan untuk perbaikan pembelajaran untuk meningkatkan prestasi belajar Agama Hindu dengan menggunakan model pembelajaran Creative Problem Solving dengan metode pemberian tugas individu dalam kerja kelompok. Peneliti telah giat melakukan kegiatan yang susuai dengan kebenaran teori yang ada sehingga peneliti memperoleh hasil yang lebih baik dari proses awal, yaitu dengan rata rata nilai 73,57 dari jumlah nilai 2060 seluruh siswa di kelas VI SD Negeri 1 Bakbakan, dan prosentase ketuntasan belajarnya adalah $64,28 \%$, yang tidak tuntas adalah 35,71\%. Hasil ini belum maksimal, karena belum mecapai indikator keberhasilan penelitian yang mencanangkan dengan minimal prosentase ketuntasan belajar $85 \%$.

3) Hasil Pada siklus II,

Dengan tindakan yang sangat maksimal dan pelaksanaan yang betul-betul mengikuti kebenaran teori sesuai dengan model pembelajaran Creative Problem Solving dengan metode pemberian tugas individu dalam kerja kelompok dalam pembelajaran Agama Hindu di kelas VI SD Negeri 1 Bakbakan, dimana hasil yang diperoleh pada siklus II ini ternyata prestasi belajar Agama Hindu meningkat secara signifikan dengan nilai rata-rata 84,28, dan ketuntasan belajarnya adalah 96,42\%.

Data awal yang diperoleh dengan rata-rata 65,35 dengan ketuntasan belajar hanya mencapai 28,57\% menunjukkan bahwa kemampuan anak/siswa dalam mata pelajaran Agama Hindu masih sangat rendah mengingat kriteria ketuntasan belajar siswa untuk mata pelajaran ini di SD Negeri 1 Bakbakan adalah 75. Hal ini dikarenakan metode yang digunakan masih bersifat konvensional, dan guru hanya berceramah dalam menyampaikan materi sehingga siswa kesulitan dalam menerima pelajaran. Dengan nilai yang sangat rendah seperti itu maka peneliti mengupayakan untuk dapat meningkatkan prestasi belajar siswa menggunakan model Creative Problem Solving dengan metode pemberian tugas individu dalam kerja kelompok. Akhirnya dengan penerapan model Creative Problem Solving dengan metode pemberian tugas individu dalam kerja kelompok yang benar sesuai teori yang ada, peningkatan rata-rata prestasi belajar siswa pada siklus I dapat diupayakan dan mencapai rata-rata 73,57. Namun rata-rata tersebut belum maksimal karena hanya 18 siswa memperoleh nilai di atas KKM sedangkan yang lainnya 
belum mencapai KKM. Sedangkan prosentase ketuntasan belajar mereka baru mencapai $64,28 \%$. Hal tersebut terjadi akibat penggunaan model Creative Problem Solving dengan metode pemberian tugas individu dalam kerja kelompok belum maksimal dapat dilakukan disebabkan penerapan model/metode tersebut baru dicobakan sehingga guru masih belum mampu melaksanakannya sesua alur teori yang benar.

Pada siklus ke II perbaikan prestasi belajar siswa diupayakan lebih maksimal dengan peneliti membuat perencanaan yang lebih baik, menggunakan alur dan teori dari model Creative Problem Solving dengan metode pemberian tugas individu dalam kerja kelompok dengan benar dan lebih maksimal. Peneliti giat memotivasi siswa agar giat belajar, memberi arahan-arahan, menuntun mereka untuk mampu menguasai materi pelajaran pada mata pelajaran Agama Hindu lebih optimal. Akhirnya dengan semua upaya tersebut peneliti mampu meningkatkan prestasi belajar siswa pada siklus II menjadi ratarata 84,28 dengan ketuntasan belajar mencapai $96,42 \%$. Upaya-upaya yang maksimal tersebut menuntun pada suatu keberhasilan bahwa penggunaan model pembelajaran Creative Problem Solving dengan metode pemberian tugas individu dalam kerja kelompok mampu meningkatkan prestasi belajar Agama Hindu siswa kelas VI semester II SD Negeri 1 Bakbakan tahun pelajaran 2017/2018.

Hasil di atas, dapat digambarkan pada grafik berikut.

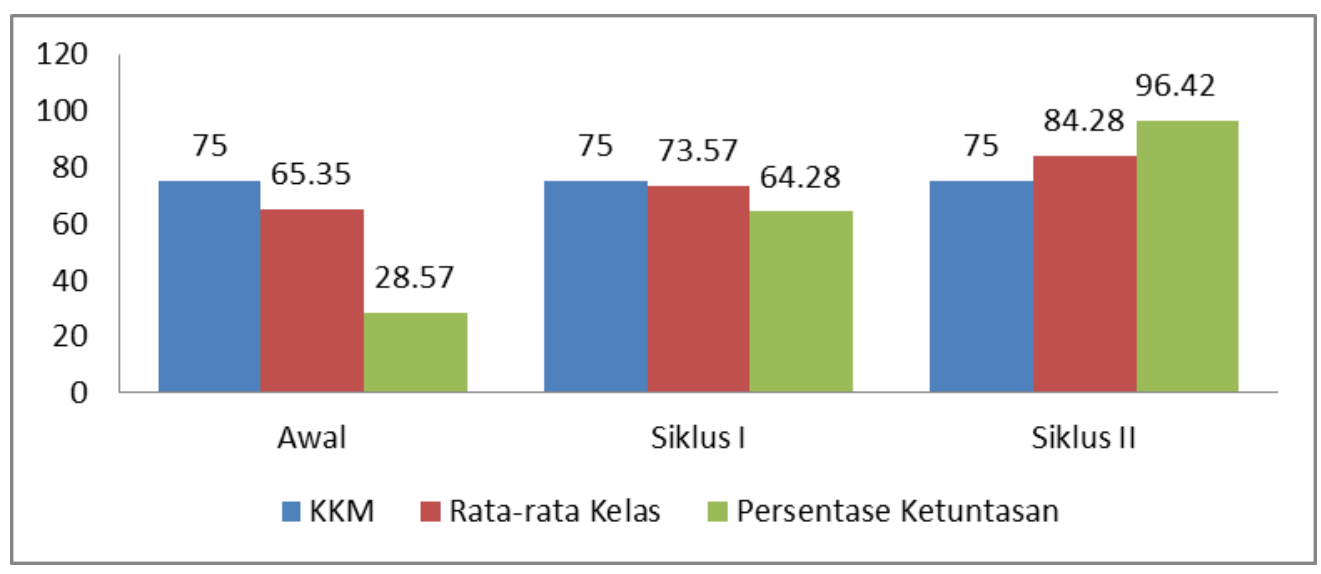

Gambar 2. Grafik Histogram Prestasi Belajar Agama Hindu Siswa Kelas VI Semester II Tahun Pelajaran 2017/2018 SD Negeri 1 Bakbakan.

Hasil penelitian ini sejalan dengan hasil penelitian yang dilakukan oleh Syamsu pada tahun 2016 yang berjudul Penerapan Model Creative Problem Solving (CPS) untuk Meningkatkan Kemampuan Berpikir Kreatif Peserta Didik Kelas XI MIA 1 SMA Negeri 1 Bulukumba (Studi pada Materi Pokok Laju Reaksi). Hasil penelitiannya menunjukkan bahwa: persentase kemampuan berpikir kreatif peserta didik pada siklus I yaitu $56,67 \%$ pada kategori tinggi dan $43,33 \%$ pada kategori sedang, pada siklus II meningkat $6,67 \%$ pada kategori sangat tinggi, $80,00 \%$ pada kategori tinggi dan $13,33 \%$ pada kategori sedang serta memenuhi indikator keberhasilan yaitu paling sedikit $70,00 \%$ mencapai kategori tinggi dan sangat tinggi.

\section{Simpulan Dan Saran}

Hasil Paparan di atas membuktikan bahwa model pembelajaran Creative Problem Solving dengan metode pemberian tugas individu dalam kerja kelompok dapat memberi jawaban sesuai tujuan penelitian ini, yaitu penggunaan model pembelajaran Creative Problem Solving dengan metode pemberian tugas individu dalam kerja kelompok mampu meningkatkan prestasi belajar Agama Hindu siswa kelas VI semester II SD Negeri 1 Bakbakan tahun pelajaran 2017/2018. Semua ini dapat dicapai karena model pembelajaran Creative Problem Solving dengan metode pemberian tugas individu dalam kerja kelompok sangat efektif diterapkan dalam proses pembelajaran yang mengakibatkan siswa aktif, antusias dan dapat memahami materi yang diajarkan sehingga prestasi belajar siswa menjadi meningkat

Berdasarkan simpulan di atas, dapat diberikan beberapa saran sebagai berikut. Siswa disarankan untuk serius dan bersemangat dalam belajar, sehingga tujuan pembelajaran dapat dicapai secara maksimal. Guru disarankan untuk mengembangkan pembelajaran dengan menggunakan berbagai macam pembelajaran inovatif, sehingga siswa tidak cepat jenuh dalam belajar. Sekolah disarankan untuk menyediakan sarana dan prasarana yang memadai dalam pelaksanaan proses pembelajaran. 


\section{Daftar Rujukan}

Arends, Richard I. 2004. Learning to Teach. Sixth Edition. New York: McGraw-Hill.

Arikunto Suharsimi, Suhardjono, Supardi. 2006. Penelitian Tindakan. Kelas. Jakarta: Bumi Aksara.

Arsyad, Azhar. 2006. Media Pembelajaran. Jakarta: Rineka Cipta.

Asikin dan Pujiadi. Lembaran Ilmu Kependidikan Jilid 37, NO. 1, Juni 2008. Pengaruh Model Pembelajaran Matematika Creative Problem Solving (CPS) Berbantuan Cd Interaktif Terhadap Kemampuan Pemecahan Masalah Pada Siswa Kelas XSMA Negeri 1 Semarang. FMAgama Hindu Unnes.

Buchori, 2012. Artikel Hasil Penelitian. Pengaruh Model Pembelajaran Matematika Creative Problem Solving (CPS) Berbantuan Software GeogebraTerhadap Kemampuan Pemecahan Masalah Pada Siswa SMA. Fakultas Pendidikan Matematika Dan Ilmu Pengetahuan Alam. IKIP PGRI Semarang.

Buchori, Nur Syamsudin. 2012. Koperasi Syariah Teori dan Praktik. Banten: Pustaka Aufa Media.

Dewi, E P. 2008. SkrAgama Hindui.Pengaruh Penggunaan model pembelajaran Creative Problem Solving (CPS) dalam Pembelajaran Agama Hindu terhadap Kemampuan Penalaran Adaptif Matematika Siswa SMA. FPMAgama Hindu UPI. Bandung.

Idrus, Muhammad. 2009. Metode Penelitian Ilmu Sosial, Pendekatan Kualitatif dan Kuantitatif, Jakarta : Erlangga.

Jayadiningrat, M. G., Tika, I. N., \& Yuliani, N. P. (2017). Meningkatkan Kesiapan Dan Hasil Belajar Siswa Pada Pembelajaran Kimia Dengan Pemberian Kuis Di Awal Pembelajaran. Jurnal Pendidikan Kimia Indonesia, 1(1), 7-12.

Rahman, B. 2009.SkrAgama Hindui.Perbandingan Kemampuan Koneksi Matematik Siswa yang Pembelajarannya Menggunakan Model Creative Problem Solving (CPS) dengan Siswa yang Pembelajarannya Menggunakan Model Konvensional. FPMAgama Hindu UPI. Bandung.

Sanjaya, Wina. 2010. Strategi Pembelajaran Berorientasi Standar Proses. Pendidikan. Jakarta : Prenada Media Group.

Saud, Udin Syaefudin. 2012. Pengembangan Profesi Guru. Bandung: Alfabeta.

Syamsu. Syari Ahmad, dkk. 2016. Penerapan Model Creative Problem Solving (CPS) untuk Meningkatkan Kemampuan Berpikir Kreatif Peserta Didik Kelas XI MIA 1 SMA Negeri 1 Bulukumba (Studi pada Materi Pokok Laju Reaksi). Jurnal Chemica UNM Vol. 17 Nomor 2 Desember 2016, 63 - 74.

Wepe, Sakalus. 2016. Pengaruh Model Pembelajaran Kooperatif Tipe Artikulasi dengan Peta Konsep terhadap Motivasi dan Hasil Belajar IPA-Biologi Siswa (Pokok Bahasan Ekosistem Kelas VII SMPN 11 Jember Tahun Pelajaran 2015/2016) . Jurnal Edukasi Unej 2016

Yuzarion . 2017. Faktor Yang Mempengaruhi Prestasi Belajar Peserta Didik . Ilmu Pendidikan, Volume 2 Nomor 1, Juni 2017. 